\title{
ArTYKuŁY
}

Klio. Czasopismo poświęcone dziejom Polski i powszechnym PL ISSN 1643-8191, t. 35 (4)/2015, s. 85-99

(c) $($ ) $\ominus$

http://dx.doi.org/10.12775/KLIO.2015.045

MACIEJ ForyCKI*

\section{Szlachta wokółbałtycka w ujęciu encyklopedystów ${ }^{* * *}$}

\section{Baltic nobility in terms of Encyclopaedists}

Streszczenie: Artykuł poświęcony jest migracji szlachty w całym basenie Morza Bałtyckiego i w szerokiej perspektywie czasowej, ale z ograniczeniem do oglądu sprawy w kręgu niezwykle wpływowych współredaktorów słynnej Encyklopedii francuskiej. W swej istocie stanowi też pretekst do refleksji nad źródłami kilku bardzo wymownych i wciąż żywotnych osądów na temat mieszkańców krain nadbałtyckich, a więc w optyce osiemnastowiecznej zwłaszcza Danii, Szwecji, Inflant, Prus oraz ziem należących do Rzeczypospolitej. Dodać do tego należy oczywiście Rosję, nie tylko z impetem wkraczającą w ów świat, ale cieszącą się też wyjątkowymi względami sporej części koryfeuszy francuskiego oświecenia.

Abstract: The article is devoted to migration of the nobility across the Baltic Sea but is restricted to the view of highly influential co-editors of the famous French Encyclopedia. There is also a pretext for reflection on the sources of some very meaningful and still

* Instytut Historii, Uniwersytet im. Adama Mickiewicza, ul. Umultowska 89d, 61-614 Poznań; e-mail: forycki@uam.edu.pl.

** Artykuł powstał w ramach programu Ministra Nauki i Szkolnictwa Wyższego pod nazwą „Narodowy Program Rozwoju Humanistyki” w latach 2012-2015 (grant nr 0156/ FNiTP/H12/80,2011). 
vital judgments about the inhabitants of the Baltic lands in $18^{\text {th }}$ century especially in Denmark, Sweden, Livonia, Prussia and the lands belonging to the Polish-Lithuanian Commonwealth. It should be also mentioned the fact that the Russian Empire, not only entering with an impetus in this world, but also possessing a unique graces of large part of the French Enlightenment philosophers.

Słowa kluczowe: szlachta, migracje, region bałtycki, Wielka Encyklopedia Francuska, Wolter

Keywords: nobility, migrations, Baltic Sea region, The Encyclopedia of Diderot \& d'Alembert, Voltaire

$\mathrm{M}$

igracje szlachty w basenie Morza Bałtyckiego w dobie nowożytnej warto prześledzić przez pryzmat opinii, jakie wykształciły się na ich temat na Zachodzie. O ile w XVI i XVII stuleciu świat bałtycki wzbudzał wciąż niewielkie zainteresowanie w Rzymie, Paryżu czy Londynie, o tyle w dobie oświecenia elity zachodnioeuropejskie już niepomiernie więcej o nim wiedziały. Liczni ich przedstawiciele znali go z autopsji, nierzadko współkreując życie kulturalne czy biorąc czynny udział w doniosłych wydarzeniach, co miało oczywiście wpływ na wzrost rzetelności informacji w obiegu publicznym.

Kwestią o pierwszorzędnym znaczeniu jest jednak to, że w XVIII stuleciu ukuto na Zachodzie szereg stereotypów dotyczących mieszkańców krain wokółbałtyckich, a wiele $\mathrm{z}$ owych klisz pozostaje tam po dziś dzień elementem zbiorowych wyobrażeń. Kluczową rolę odegrali w tym względzie encyklopedyści, na niespotykaną wcześniej skalę rozpowszechniający nie tylko wiedzę, ale przecież także własne przekonania i przesądy. Rzecz to nie bez znaczenia, jeśli wziąć pod uwagę już tylko to, że niejeden zachwycał się Karolem XII, ucztował u Stanisława Leszczyńskiego, drwił z Fryderyka Wielkiego czy służył Katarzynie II.

Tytułowa problematyka dotyczy migracji szlachty w całym basenie Morza Bałtyckiego i w szerokiej perspektywie czasowej, ale z ograniczeniem do oglądu sprawy w kręgu niezwykle wpływowych współredaktorów słynnego Stownika rozumowanego ${ }^{1}$. W swej istocie stanowi też pretekst do

${ }^{1}$ Encyclopédie, ou dictionnaire raisonné des sciences, des arts et des métiers, par une société de gens de lettres. Mis en ordre \& publié par M. Diderot, de l'Académie Royale des 
refleksji nad źródłami kilku bardzo wymownych i wciąż żywotnych osądów na temat mieszkańców krain nadbałtyckich, a więc w optyce osiemnastowiecznej zwłaszcza Danii, Szwecji, Inflant, Prus oraz ziem należących do Rzeczypospolitej². Dodać do tego należy oczywiście Rosję, nie tylko z impetem wkraczającą w ów świat, ale cieszącą się też wyjątkowymi względami sporej części koryfeuszy francuskiego oświecenia ${ }^{3}$.

Zagadnienie zostanie przedstawione w czterech odsłonach. W pierwszej kolejności należy koniecznie przypomnieć ewolucję zachodnioeuropejskiego oglądu spraw bałtyckich w XVIII stuleciu. Celnym pretekstem do ukazania, jak nabierał ostrości obraz świata bałtyckiego, mogą być hasła podstawowe Stownika rozumowanego „Bałtyk” i „Rosja”, odległe położeniem alfabetycznym, a zarazem chronologicznym (z górą dekada różnicy między ich publikacja). Drugim zagadnieniem, które trzeba bezwzględnie zamarkować, jest znaczenie mitów założycielskich ludów wokółbałtyckich, problematyka mająca co prawda wątpliwą wartość historyczną, lecz silnie obecna w oświeceniowym rozumieniu dziejów migracji w basenie Morza Bałtyckiego, zwłaszcza w postrzeganiu tego regionu jako kolebki ludów germańskich i słowiańskich. Obszerniejszej analizy wymagają oczywiście migracje szlachty wokółbałtyckiej. Zagadnienie można ująć w dwa przeciwstawne przypadki: pierwszy z nich dotyczy mobilności szlachty wolnej, a wzorami dla niego będą modele szwedzki i polski; drugi natomiast wy-

Sciences \& des Belles-Lettres de Prusse; \&r quant à la Partie Mathématique, par M. D’Alembert, de l'Académie Royale des Sciences de Paris, de celle de Prusse, ó de la Société Royale de Londres, t. 1-17, Paris 1751-1772. Odnośnie do monumentalnego dzieła używamy poniżej oryginalnego zapisu tytułu hasła wraz z przyporządkowaną mu kategorią encyklopedyczną, a dalej zaznaczając tom i stronę, gdzie hasło jest umieszczone, np.: BALTIQUE, (Mer) Géog., t. 2, s. 49.

2 Problematyka podjęta w tekście nie była dotąd przedmiotem badań naukowych. Studia nad zagadnieniem podjęto jedynie w odniesieniu do Rzeczypospolitej szlacheckiej: M. Forycki, Odmienności szlachty Rzeczypospolitej w ujęciu myślicieli oświecenia, [w:] Szlachta-granice etniczne, wyznaniowe i cywilizacyjne, red. T. Ciesielski (w druku); idem, Chorografia Rzeczypospolitej szlacheckiej w Encyklopedii Diderota i d'Alemberta, Poznań 2010.

${ }^{3}$ Por. zwłaszcza A. Lortholary, Le mirage russe en France au XVIII'me siècle, Paris 1951 oraz M. Belissa, La Russie mise en Lumières. Représentations et débats autour de la Russie dans la France du XVIII siecle, Paris 2010. 
maga krótkiego, acz dobitnego zarysowania problematyki rosyjskiej, czyli encyklopedycznego mirażu carskiej misji cywilizacyjnej.

\section{Hasła „Baltique” i „Russie”, czyli wyostrzający się obraz świata bałtyckiego}

Zacząć wypada od zdefiniowania przestrzeni wokółbałtyckiej, tak jak rozumiała ją Wielka Encyklopedia Francuska. Krótki artykuł autorstwa samego Diderota przedstawia Bałtyk, jako morze położone entre l'Ailemagne [sic!] \& la Pologne, qui a au midi le Danemarck, la Suede à l'occident, la Laponie au septentrion, la Bothnie, la Finlande, la Livonie, la Curlande, une partie de la Pologne à l'orient ${ }^{4}$, eksponując dodatkowo znaczenie cieśnin duńskich: Sundu oraz Małego i Wielkiego Bełtu. To bardzo schematyczna definicja, wskazuje jednak przestrzeń naszych zainteresowań, a więc nadmorskie krainy niemieckie, Polskę, Danię, Szwecję z podległymi jej ziemiami północno-wschodnimi, Inflanty i Kurlandię. Można się dziwić, że autor hasła nie wyodrębnił Żmudzi, czy choćby nie wspomniał Litwy, pod terminem Polska ujmując pewnie całą Rzeczpospolitą szlachecką.

Przede wszystkim jednak z miejsca odnotujmy, że brak w tej definicji jakiejkolwiek wzmianki o Rosji. Jest to ubytek niezwykle wymowny - przypomnijmy choćby, że artykuł powstał pół stulecia po założeniu Petersburga! Jest to wymowne świadectwo schyłku epoki, w której świat wokółbałtycki w znikomym stopniu interesował elity intelektualne Zachodu. Dezynwoltura wynikała więc po prostu z niewiedzy i pośpiechu redaktora monumentalnego dzieła.

Dla niniejszych rozważań banalne w swej treści hasło „Bałtyk” nabiera więc bardzo wymownego znaczenia: w optyce czołowego dzieła propagującego wiedzę oświeconych brak, w 1752 roku, rosyjskiej obecności nad Bałtykiem. Nie jest to przypadek odosobniony, lecz jedno z wielu świadectw braku orientacji Zachodu w sprawach Północy. Co więcej, jest to przykład obiegowej opinii w kręgach ówczesnych elit intelektualnych, których znikoma wiedza o sytuacji geopolitycznej odległej części kontynentu

${ }^{4}$ BALTIQUE, (Mer) Géog., t. 2, s. 49. 
nie odnotowała jeszcze ekspansji państwa carów nad Bałtyk, nie mówiąc już o związanej z nią migracji szlachty. Swoista tabula rasa encyklopedystów, zobrazowana tu artykułem „Bałtyk” z drugiego tomu Stownika rozumowanego, została bardzo szybko zapisana, o czym świadczyć może chociażby hasło „Rosja” (tom XIV, wydany w 1765 roku), uczące, że Pierre le grand a ouvert la mer Baltique à ses états5.

\section{Znaczenie mitów założycielskich szlachty wokółbałtyckiej}

Morze Bałtyckie uznano w Encyklopedii Diderota i d'Alemberta za kolebkę cywilizacji germańskiej ${ }^{6}$. Rzecz bardzo wymowna - koryfeusze oświecenia budowali dzieje szlachty poszczególnych krain w oparciu o mity założycielskie, stosunkowo dużo miejsca poświęcając też rozważaniom o wczesnych losach nadbałtyckich ludów, które opierali na świadectwach starożytnych (w przypadku bałtyckim zwłaszcza na Ptolemeuszu i Pomponiuszu Meli).

Kluczową rolę w dziejach Bałtyku odegrać miała Codanonia, którą encyklopedysta identyfikował z największą z duńskich wysp - Zelandią (duń. Sjalland). Za Jacobem Carlem Spenerem ${ }^{7}$ wskazywano, że Teutonowie migrowali z wyspy, rozlewając się po świecie bałtyckim. Mieli sprzymierzać się czy wręcz asymilować z Sasami, Duńczykami i Normanami. Późniejszym przykładem starożytnych migracji z basenu Morza Bałtyckiego byli Rugiowie, których dzieje - między innymi za Tacytem, Jordanesem

${ }^{5}$ RUSSIE, (Geog. mod.), t. 14, 442. Warto przypomnieć, że źródłem opinii na temat Północy podzielanych przez francuskie elity intelektualne epoki były przede wszystkim dwa dzieła tego samego autora - Woltera: Histoire de Charles XII roi de Suède (Historia Karola XII króla Szwecji) oraz Historie de l'Empire de Russie sous Pierre le Grand (Historia Imperium Rosyjskiego za Piotra Wielkiego). Przywołany tu artykuł „Rosja” został podpisany przez kawalera de Jaucourt, powiela jednak treści drugiego z Wolterowych dzieł, które ukazało się drukiem w 1760 r. (tom 1) i 1763 r. (tom 2) a stanowi fundamentalną cezurę w wiedzy encyklopedystów o państwie carów. Zob. współczesne, renomowane wydanie Bibliothèque de la Pléiade: Voltaire, Histoire de l'Empire de Russie sous Pierre le Grand, [w:] idem, Euvres historiques, wyd. R. Pomeau, Paris 1957, s. 339-598.

6 TEUTONS, les, (Géog. anc.), t. 16, s. 214-215.

7 J. C. Spener, Notitia Germaniae antiquate cum conspectu Germaniae antiquiae cum caonspectu Germaniae mediae, Halle 1717. 
czy Prokopiuszem - encyklopedyści śledzili od siedzib nadbałtyckich, przez naddunajskie, aż po apenińskie ${ }^{8}$.

Ciekawy przykład rozważań nad najdawniejszymi dziejami ludów bałtyckich znaleźć można w artykule „Morze” współautorstwa d'Alemberta i barona d'Holbacha ${ }^{9}$. Encyklopedyści, idąc za teoriami Olofa von Dalina ${ }^{10}$, zanegowali powszechne mniemanie, jakoby migracje ludów północnej Europy mogły rozprzestrzeniać się od Skandynawii. Teorie te oparte były na nowych badaniach naukowych, które wskazywały, że w stosunkowo nieodległych wiekach rozległe tereny Skandynawii były pokryte lodowcem lub morzem. Encyklopedyści podkreślali, że owe teorie miały niezwykle donośne znaczenie, negowały bowiem starożytne pochodzenie szlachty skandynawskiej, którego zawsze jej zazdroszczono. Pisali nawet o dyshonorze dla Szwecji, niebędącej, jak dotąd mniemano, zaludnioną przez potomków Noego w linii prostej.

Morze Bałtyckie miałoby być także kolebką ludów słowiańskich. W artykule „Esclavon” ${ }^{11}$ przedstawiono dwie teorie na ten temat. Pierwsza, oparta na wydanych przez Leibniza kronikach Helmolda i Arnolda z Lubeki ${ }^{12}$, wskazywała, że Słowianie zamieszkujący u zarania wybrzeża bałtyckie dzielili się na wschodnich i zachodnich, przy czym do pierwszej grupy encyklopedysta zalicza Wandalów, a z drugiej wymienia Rosjan, Polaków czy Czechów. Drugą z teorii podano za słynnym dziełem chorwackiego dziejopisa Mauro Orbiniego z początku XVII wieku ${ }^{13}$, wskazując na ziemie fińskie jako kolebkę ludów słowiańskich.

8 RUGIENS, LES, Rugii, (Géog. anc.), t. 14, s. 432.

9 MER, s. f. (Géog.), t. 10, s. 359.

10 O. von Dalin, Then Swänska Argus, Stockholm 1732-1734.

11 ESCLAVON, s. m. (Hist. mod.) ou LANGUe ESCLAVONne, t. 5, s. 943.

12 Scriptorum Brunsvicensia illustrantium, wyd. G. W. Leibnitz, t. 2, Hanovrae 1710, s. 629-751.

13 M. Orbini, Il regno de gli Slavi, hoggi corrottamente detti Schiavoni, Pesaro 1601. 


\section{Migracje szlachty wolnej}

1. Wzór szwedzki, czyli znaczenie migracji szlachty do miast

Casus migracji szlachty szwedzkiej uznać można za modelowy dla encyklopedycznego obrazu przemian społecznych w Skandynawii ${ }^{14}$. Z rozproszonych w wielotomowym dziele informacji ukazuje się pięcioetapowy proces dziejowy właściwy tamtejszym elitom społecznym. Dla czasów najdawniejszych uznano równomierne i stosunkowo gęste zaludnienie kolebki ludów germańskich (teoria podana w wątpliwość w związku z odkryciami dotyczącymi zlodowacenia Skandynawii, o czym wyżej). Drugim etapem procesu miały być, według encyklopedystów, masowe migracje ludów na południe. Dalszy rozwój przebiegać miał natomiast dwutorowo: tereny wyludnione popadły w barbarzyństwo, a południowa część Skandynawii - dzięki tak gloryfikowanemu przez oświeconych postępowi - z wolna się cywilizowała, na co korzystny wpływ miał mieć panujący ówcześnie despotyzm. W takiej optyce historiozoficznej - dzięki migracjom, postępowi i silnej władzy wykształciła się szwedzka hierarchia społeczna. Jej elity otworzyły ostatni etap procesu dziejowego nacechowany wolnością, rozkwitem Sztokholmu i oświecającą misją szlachty ${ }^{15}$.

W ważnym artykule „Assemblée” ${ }^{16}$ wskazano, że zgromadzenia parlamentarne w Szwecji i Polsce zachowały swoje prerogatywy, których źródeł encyklopedysta poszukiwał w wiecach z czasów gockich. Parlamentaryzm szwedzki miał w optyce encyklopedycznej rolę przyciągającą szlachtę do stolicy. Sztokholm miał odgrywać dzięki temu rolę ośrodka władzy szlacheckiej, stolicy wolności i oświecenia ${ }^{17}$. Przykład ten stanowił dla encyklopedystów antymodel dla scentralizowanej monarchii duńskiej.

Obraz szlachty szwedzkiej migrującej do stolicy i fundującej tam ośrodek wolności politycznej, mecenatu kulturalnego i swoistej latarni oświecenia ma jednak przede wszystkim ogromne znaczenie jako ideał na

\footnotetext{
${ }^{14}$ Zob. zwłaszcza SUEDE, (Géog. mod.), t. 15, s. 623-624.

15 Ibidem, passim.

16 ASSEMBLÉE, s. f. (Hist. \& Jurisprud.), t. 1, s. 767.

17 STOCKHOLM, (Géogr. mod.), t. 15, s. 522-523.
} 
skalę europejską. Należy go bowiem przeciwstawić przypadkowi rosyjskiemu (migracja do Petersburga, rozkwit oświecenia, ale całkowity brak swobody politycznej) oraz rzecz jasna wersalskiemu (napływ szlachty usłużnej na dwór monarchy zwalczającego poglądy encyklopedystów $)^{18}$.

W definicji Sztokholmu kawaler de Jaucourt zachwyca się między innymi pięknymi budowlami szlacheckimi. Zamek królewski, jak podkreśla, jest nie tylko rezydencją monarchy, ale także siedzibą innych instytucji politycznych. Wymienia ponadto pałac kanclerza, Dom Rycerstwa i pałace szlacheckie. Eksponuje zwłaszcza znaczenie Domu Rycerstwa, w którym odbywają się zgromadzenia szlacheckie.

Przypomnijmy, że zachwyt nad szlacheckimi budowlami Sztokholmu miał dla encyklopedystów ważne aluzje dziejowe - wiele z nich, z Domem Rycerstwa na czele, powstało dzięki francuskiemu hugenocie Simonowi de la Vallée i jego synowi Jeanowi de la Vallée.

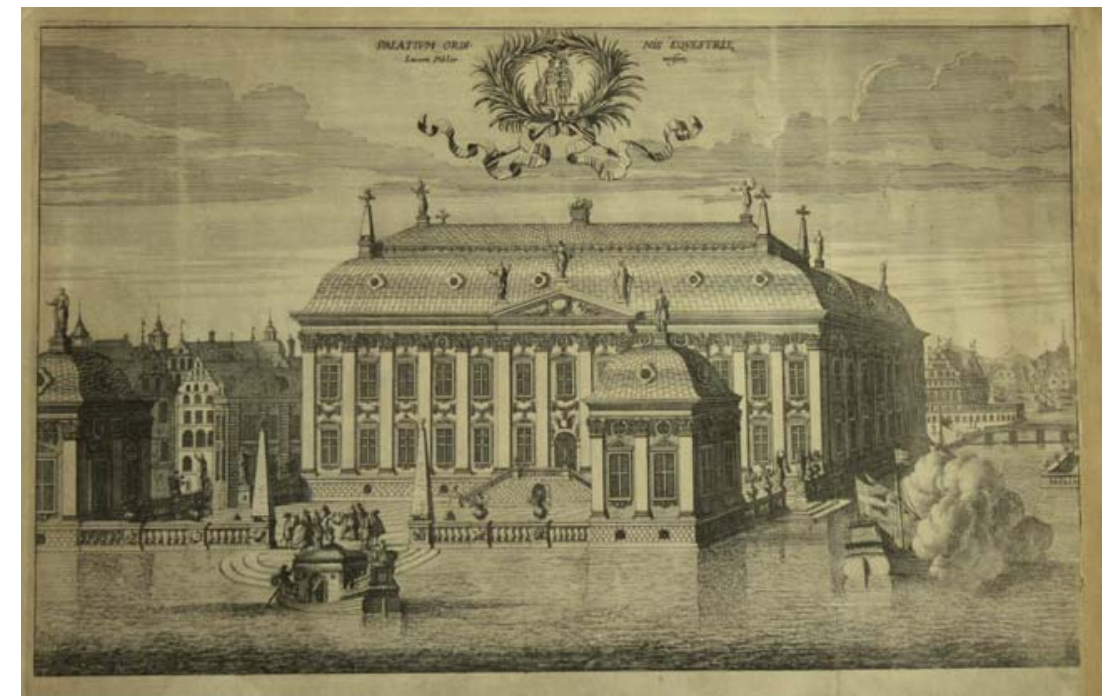

Dom Rycerstwa (Riddarbuset) w Sztokholmie - bastion wolności wzniesiony przez hugenotę

Rycina z dzieła Erika Dahlbergha pt. Suecia antiqua et hodierna (1716)

18 Por. na przykład wymowę artykułu „Sénateur de Suede”, (Hist. de Suede.), t. 15, s. 8 . 
Dyskurs encyklopedyczny nabrał wyjątkowej mocy przy wspomnieniu roku 1520, kiedy to król-tyran Chrystian II i arcybiskup Uppsali Gustaw Trolle kazali „wymordować cały senat i tak wielu uczciwych obywateli”"19. Dzięki migracji szlacheckiej stolica Szwecji stała się jednak bastionem przeciwko despotyzmowi. Dla Wieku Świateł natomiast encyklopedysta eksponuje inną ważną konsekwencję tej migracji, a mianowicie powołanie w 1735 roku (faktycznie w 1739) Akademii Nauk ${ }^{20}$.

\section{Model polski - mobilność szlachty i niezależność od stolicy}

Podobnie jak w przypadku szlachty szwedzkiej, Encyklopedia daje przykład sarmackich elit społecznych dla uwypuklenia szeregu cech pozytywnych, nieznanych w państwie władcy absolutnego. Ów model polski charakteryzuje się, w ujęciu encyklopedystów, wyjątkową mobilnością szlacheckiej warstwy rządzącej - swobodnymi migracjami, gwarantującymi niezależność od władzy centralnej ${ }^{21}$.

Dzieje Polski poprzedzał, w ujęciu Stownika rozumowanego, okres sarmacki. Podkreślaną specyfiką pradawnej organizacji społecznej był brak jedynowładztwa. Encyklopedia nie mogła trafić na lepszy model dla pokazania, do czego zdolny jest lud wolny, żyjący w stanie naturalnym. Sarmaci nie tylko, jak można by się spodziewać, nie zostali podbici (choćby przez Rzymian), ale wręcz przeciwnie, sami zdołali podporządkować sobie ogromne terytoria, rozciągające się od Bałtyku po Morze Czarne i od Donu po Wisłę. Przodkowie Polaków byli ludem licznym i znanym z bitności ${ }^{22}$. Pradawne korzenie determinowały w oczach cudzoziemców cechy charakteru Polaków, z których wiele odziedziczyć mieli oni od swych odległych przodków. Zwracano uwagę zwłaszcza na szczerość i dumę szlachty polskiej.

19 STOCKHOLM, (Géogr. mod.), t. 15, s. 523. Chodzi o wydarzenia z 8-9 XI 1520 r., znane jako krwawa łaźnia sztokholmska.

20 SUEDE, (Géog. mod.), t. 15, s. 625.

${ }^{21}$ Specyfikę migracji szlachty polskiej w ujęciu encyklopedycznym przypominam za M. Forycki, Chorografia Rzeczypospolitej szlacheckiej w Encyklopedii Diderota i d'Alemberta, Poznań 2010, s. 125-126.

${ }^{22}$ POLOGNE, histoire \& gouvernement de, (Hist. \& Droit politique), t. 12, s. 925. 
Co się zaś tyczy spawy migracji, to swego rodzaju pierwotną, nieokiełznaną wolność Sarmatów również dawano w Encyklopedii za genezę tego, że współcześnie szlachta polska jest narodem wędrownym, czerpiącym w dużej mierze przyjemność "tylko z życia tułaczego, bez stałej siedziby”23, co należy łączyć między innymi z powtarzanymi we Francji opisami podróżującego polskiego dworu królewskiego, częstych zjazdów szlacheckich, czy wreszcie co rusz odwiedzających się nawzajem braci-szlachty.

Odwołania do elity społecznej Rzeczypospolitej zostały w dykcjonarzu zawężone do kilku swoistości stanu szlacheckiego. Rzeczywiście, szlachta polska (w domyśle również litewska) została przedstawiona w sposób wyjątkowy, bo idący na przekór powszechności, a nawet jako wręcz antymodel przypadku francuskiego i - podobnie jak casus szwedzki - przykład w tym sensie zdecydowanie pozytywny. La noblesse polonaise przede wszystkim jawiła się bowiem jako silna swym przywiązaniem do prowincji, wbrew francuskiej, która nieustannie ciąży ku centrum. Znajdziemy na kartach Encyklopedii ciekawą opozycję między ową „podstawową komórką” życia lokalnego szlachty polskiej, jaką był dworek szlachecki, a dworem wersalskim - przestrzenią centralną, a chciałoby się powiedzieć też jedyną, w której francuski szlachcic mógł poczuć się, jak byśmy to dzisiaj powiedzieli, „zwierzęciem politycznym”. Dworek i Wersal - oto metafory dwóch przeciwstawnych źródeł politycznej aktywności szlachty. Chodzi tu z jednej strony o krótki, acz bardzo wyrazisty encyklopedyczny obraz lokalnej działalności szlachty polskiej, z drugiej zaś o najpierwotniejszą przyczynę mobilizacji polskiego szlachcica w sferze publicznej, tak różną od wzorca francuskiego.

W obrazie szlachcica polskiego skreślonym w Encyklopedii Diderota i d'Alemberta znajdujemy rys wyróżniający go na tle europejskich konfratrów, a mianowicie domatorstwo. „Wyśmienitym zwyczajem panów [polskich] jest spędzanie największej części roku w ich ziemiach. Stają się przez to bardziej niezależni od próbującego za wszelką cenę ich skorumpować dworu, a ożywiają też wieś wydatkami, które czynią"24. Co ważne, nie potępiono bynajmniej tego, że Sarmata spędza większą część roku w swych posiadłościach na prowincji i wcale nie przyklejono polskiemu szlachci-

${ }^{23}$ AMBULATOIRE, adj. (Jurisprud.), t. 1, s. 327.

${ }^{24}$ POLOGNE, histoire \& gouvernement de (Hist. \& Droit politique), t. 12, s. 930. 
cowi łatki zaściankowości, a przebywanie z dala od stolicy nie czyniło zeń w oczach encyklopedysty ciemnogrodzianina. Wręcz przeciwnie. Francuski tekst pochwalił ów zwyczaj polskiej szlachty i wyniósł go do rangi przykładu godnego naśladowania. Dworek szlachecki był tym samym postrzegany jako podstawowa komórka systemu społeczno-politycznego - miejsce, które dla szlachcica-obywatela jest opoką wolności. Dworek to właśnie antymodel Wersalu - miejsca, które niszczy szlachecką niezależność ${ }^{25}$.

Życie polskiego szlachcica na prowincji jawiło się encyklopedystom jako korzystnie wpływające na więzi stanowe. Francuzi pisali o częstych w Polsce zjazdach szlacheckich i powszechnym upodobaniu do wzajemnych odwiedzin (przywoływano jako przykład odległe wojaże szlacheckie, których celem miało być tylko zjedzenie kolacji w towarzystwie znajomych). Wyjątkowo przypadał do gustu także zwyczaj, że polscy szlachcice nazywają się nawzajem braćmi, uznając, że płynie w nich ta sama krew, że są jedną wielką rodziną. Tak postrzegana jednolitość polskiego stanu szlacheckiego, dodatkowo wzmocniona ideologią równości, bardzo przecież różniła go od zachodnich odpowiedników.

U schyłku lat sześćdziesiątych XVIII stulecia nastąpiła jednak gwałtowna zmiana oglądu spraw polskich nad Sekwaną. Część francuskich elit intelektualnych ostro potępiła konfederację barską, w setkach tekstów zażarcie atakując nie tylko sam ruch szlachecki, ale szerzej - państwo polskiej szlachty, jako ostoję obskurantyzmu, anarchii i katolickiego fanatyzmu. Warto tu przytoczyć wymowny przykład, a mianowicie świadectwo z podróży wybrzeżem Bałtyku samego redaktora Encyklopedii, Denisa Diderota, który w 1773 roku przejeżdżał w drodze do Petersburga przez odebrane Rzeczypospolitej ziemie pruskie.

Relacja encyklopedysty ogranicza się do żartobliwego wierszyka, skleconego w trakcie, jak sam pisze, „przejazdu przez tę część Polski dziś pruską, gdzie byliśmy pożerani przez muchy, a gdzie siedem czy osiem miesię-

${ }^{25}$ Zob. M. Forycki, Szlachta polska a europejska w Encyklopedii Diderota i d'Alemberta, [w:] Szlachta europejska w strukturach lokalnych XVI-XVIII wieku, red. M. Konopnicka, J. Kuczer, W. Strzyżewski, Zielona Góra 2010, s. 211-218. 
cy wcześniej groziłoby nam zamordowanie z rąk konfederatów”26. Jedną z głównych cech charakterystycznych polskiej szlachty, jakie przydawali jej encyklopedyści, była, jak widzieliśmy, jej wyjątkowa mobilność. Diderot wykorzystał ten atrybut w sposób pejoratywny i prześmiewczy, uosabiając natrętne insekty $\mathrm{z}$ konfederatami ${ }^{27}$.

\section{Niejednoznaczności inflanckie i casus piltyński}

W Wielkiej Encyklopedii Francuskiej bardzo niewiele miejsca poświęcono szlachcie inflanckiej, a ledwie wspomniano kurlandzką, pruską czy pomorską. Niejednoznaczności te odnotujmy tu krótko na przykładzie inflanckim i piltyńskim.

W stosownych artykułach wspomniano o migracjach możnowładztwa duńskiego, szwedzkiego, polskiego i rosyjskiego na ziemie inflanckie, podkreślając przy tym w ogólnych słowach odrębność tamtejszej szlachty rodzimej ${ }^{28}$. Wyłączając kwestie związane z dawniejszymi dziejami tych ziem (dyskurs encyklopedyczny zdominowany przez historię zakonu kawalerów mieczowych), dano jedynie obraz krainy znajdującej się pod despotyczną władzą cara, której szlachta rodzima „pilnuje swych interesów na prowincji”, a nie ma wpływów w ośrodkach miejskich zarządzanych przez uzależnione od Petersburga magistraty. Słowem, szlachta inflancka jest w definicjach encyklopedycznych niemobilna, osiadła w dobrach pozamiejskich i jakby statecznie opierająca się burzliwym wydarzeniom dziejowym. Warto w tym miejscu dodać, że podobny, choć jeszcze bardziej schematyczny, obraz dano szlachcie pomorskiej ${ }^{29}$.

${ }^{26}$ D. Diderot, Poèmes de la Haye à Saint-Pétersbourg, [w:] idem, Euvres complètes, wyd. R. Lewinter, t. 10, Paris 1971, s. 503.

${ }^{27}$ „Nikt nie patrzył tu/ Na nas kosym okiem;/ A jeśli mieliśmy z kimś/ Wojnę toczyć, to tylko z/ Muchami, muchami// Choć insekt ten/ Nie jest bestią dziką,/ To przecież nie jest rzeczą przyjemną/ Służyć za posiłek/ Muchom// Ci mali konfederaci/ Brali nas za głupców;/ Ale nie wyciągając szabel/ Uwolniliśmy się/ Od much”, ibidem, s. 503-505.

${ }^{28}$ LIVONIE, LA (Géog.), t. 9, s. 600; REVEL, (Geog. mod.), t. 14, s. 224; RIGA, (Géogr. mod.), t. 14, s. 289.

${ }^{29}$ STETIN ou STETTIN, (Géog. mod.), t. 15, s. 517. 
Osobliwą wizję intersującego nas tu problemu przedstawiono dla ziemi piltyńskiej. W haśle podmiotowym dotyczącym Piltynia ${ }^{30}$ kawaler de Jaucourt odnotował, że istniało tam dawniej biskupstwo (chodzi o diecezję kurońska), które w 1559 roku zostało zsekularyzowane przez króla duńskiego Fryderyka II, który oddał jego ziemie szlachcie. Artykuł kończy się na tym stwierdzeniu, co każe podejrzewać, że starostwo piltyńskie nadal jest zależne od Kopenhagi, a zamieszkująca je szlachta ma duńską tożsamość. Anachroniczne opisy dykcjonarza dotyczące Piltynia potraktować tu należy jako przykład wielu podobnych omyłek encyklopedycznych o świecie wokółbałtyckim.

\section{Miraż rosyjskiej migracji cywilizującej}

W zgoła odmienny sposób encyklopedyści odnosili się do migracji rosyjskich nad Bałtyk. Tytułem motta do tej trudnej problematyki niech będzie krótki wiersz Woltera skreślony na marginesie lektury słynnych na Zachodzie dziejów Północy pióra Jörana Anderssona Nordberga ${ }^{31}$ :

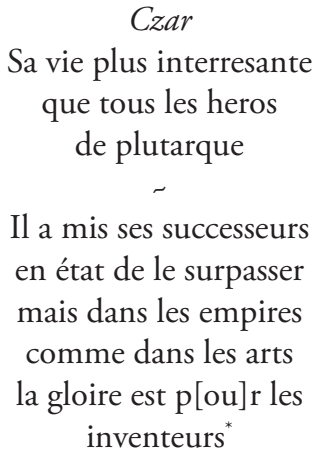

Il a mis ses successeurs en état de le surpasser mais dans les empires comme dans les arts la gloire est $\mathrm{p}[\mathrm{ou}] \mathrm{r}$ les inventeurs ${ }^{*}$

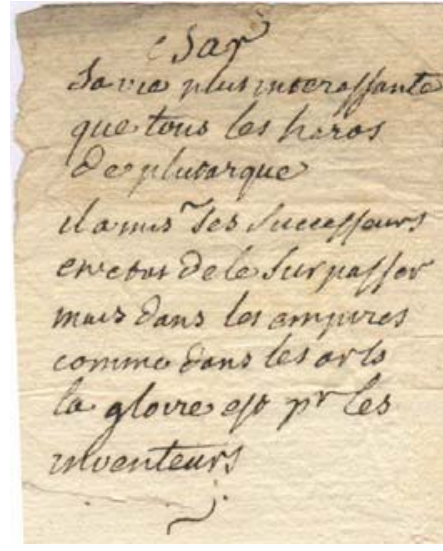

30 PILTEN, ou PILTYN, (Géog. Mod.), t. 12, s. 625.

${ }^{31}$ J. A. Nordberg, Histoire de Charles XII, roi de Suède, przekł. K.-G. Warmholtz, t. 3, La Haye 1748, inter s. 174 et 175, Российская национальная библиотека, Библиотека Вольтера, 2581, чЧ 8-226. 
* „Car/Jego żywot bardziej interesujący/Niźli wszystkich bohaterów/Plutarcha Przygotował swych następców/ by go przewyższyli/ lecz w imperiach/ niczym w sztuce/ chwała należy/ do odkrywców".

Homagium „Czar” - własnoręczna glosa Woltera na marginesie Dziejów Karola XII Nordberga. Ze zbiorów Biblioteki Woltera w Petersburgu

W bardzo wymownym ujęciu historiozoficznym zaproponowanym przez Woltera i powielanym przez wielu encyklopedystów, państwo carów przedstawiano jako barbarzyńską część kontynentu, która dopiero w dobie panowania Piotra Wielkiego została - i to w sposób drastyczny - wyrwana z zacofania. Encyklopedia przypomina między innymi, że szlachta była zmuszana do opuszczania swych majątków i przenoszenia się do nowej stolicy, a młódź arystokratyczna - siłą wcielana do armii ${ }^{32}$.

Nowe spojrzenie części elit Zachodu na Rosję, podążające za opiniami najbardziej w tej materii głośnego Woltera, definiowało państwo carów jako doskonałą przestrzeń, w której zrealizować się mogą wartości Oświecenia. Parafrazując Wolterowe hasło „C'est du Nord aujourd'hui que nous vient la Lumière" ${ }^{33}$, to z Petersburga i Moskwy rozlewać się miały po Europie ideały Oświecenia. Nawiązując do mitycznych korzeni scytyjskich, ukuto w sposób niezwykle wymownie i trwały stereotyp nowej Rosji oparty na oryginalnym pomyśle ewolucyjnym jej szlacheckich elit: figurze Scyty, który przepoczwarzył się w cywilizowanego Rosjanina, rychło dojrzałego do pouczania Europy ${ }^{34}$.

W takiej perspektywie migracje szlachty w basenie Morza Bałtyckiego nabierają zupełnie nowych wymiarów. Rosyjskie elity społeczne przybyły nad ujście Newy, aby na ziemi pustej, dzikiej, barbarzyńskiej wznieść stolicę oświeconego świata. Szlacheckie elity wojskowe rozlewały carskie pułki

32 PETERSBOURG, (Géog. mod.), t. 12, s. 464.

33 „To z Północy przychodzi dziś do nas Światło” - aleksandryn ten zamyka wierszowany list do Katarzyny II z 1771 r. Voltaire, Épitre à l'Impératrice de Russie, Cathérine II, [w:] idem, Euvres complètes, wyd. L. Moland, t. 10, Paris 1877, s. 274.

${ }^{34} \mathrm{~W}$ swej sławnej Filozofii historii Wolter ujął rzecz obrazowo, deprecjonując starożytne korzenie Europy w porównaniu z modelem scytyjsko-rosyjskim: „W ciągu pół wieku dwór Scytów stał się bardziej oświecony niż były kiedykolwiek Grecja i Rzym”, Voltaire, La Philosophie de l'histoire, wyd. J. H. Brumfitt, [w:] Euvres complètes de Voltaire, t. 59, Genève 1969, s. 138-139. 
po nowych ziemiach, aby nieść kaganek cywilizacji. Migracje rosyjskie na Zachód nie były ekspansją, lecz misją cywilizacyjną:

wielkie zdziwienie wywołała ta armia rosyjska przebywająca w Polsce w większej dyscyplinie, niźli kiedykolwiek oddziały polskie. Nie było najmniejszego bałaganu. Wzbogacała ona kraj, zamiast go dewastować, stacjonowała tam jedynie, aby bronić tolerancji; te obce oddziały musiały dać przykład mądrości; i dały. Można by wziąć tę armię za sejm, który zebrał się na rzecz wolności ${ }^{35}$.

Wojsko rosyjskie było w tej optyce armią humanitarną, niosącą wybawienie od wynaturzeń barbarzyństwa, w tym zwłaszcza koszmaru nietolerancji. Wolter widział w żołnierzach carskich maszerujących od Bałtyku po ziemie ukrainne Rzeczypospolitej pierwszą armię pokoju w dziejach ludzkości:

Imperatorowa Rosji nie tylko wprowadziła powszechną tolerancję w swych ogromnych krajach, ale także wysłała armię do Polski, pierwszą tego rodzaju odkąd ziemia istnieje, armię pokoju, która służy obronie praw obywateli i przeraża prześladowców ${ }^{36}$.

Na przeszkodzie tej wyjątkowej migracji stała zanarchizowana i nietolerancyjna szlachta polska, owe Diderotowe namolne muchy, które encyklopedyści zdefiniowali jako wroga na przełomie lat sześćdziesiątych i siedemdziesiątych XVIII stulecia, a więc w czasach ogłoszenia drukiem

${ }^{35}$ Idem, Essai historique et critique sur les dissentions des Églises de Pologne, par Joseph Bourdillon, professeur en Droit public, wyd. D. Beauvois, E. Rostworowski, [w:] idem, Euvres complètes, t. 63A, („Studies on Voltaire and the Eighteenth Century”), Oxford 1990, s. 289.

${ }^{36}$ Idem, Sermon prêché à Bâle le premier jour de l'an 1768, par Josias Rossette, [w:] idem, Mélanges, („Bibliothèque de la Pléiade”), Paris 1961, s. 1321. Oczywiście także w swej korespondencji Wolter nie przestaje zachwycać się polityką Katarzyny II: „przykład, który daje Imperatorowa Rosji jest wyjątkowy w skali światowej. Wysłała ona czterdzieści tysięcy Rosjan, by głosili tolerancję z bagnetem na końcu strzelby”. List Woltera do Jeana Le Rond d'Alemberta, 3 V 1767, Voltaire's Correspondence, wyd. T. Besterman, 13261. Podobną euforię wyraził w liście do markizy Du Deffand, 18 V 1767, ibidem, 13293 oraz do Etienne’a Noëla Damilaville’a, 4 września 1767, ibidem, 13505. 
ostatnich tomów Stownika rozumowanego. Obraz ten - oczywiście kreowany przez propagandę rosyjską - niestety na stałe zakorzenił się w świadomości zachodnioeuropejskiej. Elity intelektualne Zachodu uległy pod wpływem agitacji rosyjskiej ułudzie zbawczej dla Europy roli państwa carów, a dyskurs encyklopedyczny utrwalił tę wizję. Zjawisko to, znane badaczom osiemnastego wieku jako „miraż rosyjski”, odradza się po dziś dzień. 